\title{
Surface deformations associated with the October 2004 Mid-Niigata earthquake: Description and discussion
}

\author{
Kim Haeng Yoong ${ }^{1}$ and Atsumasa Okada ${ }^{2}$ \\ ${ }^{1}$ Earthquake Research Institute, University of Tokyo, 113-0032, Japan \\ ${ }^{2}$ Division of Earth and Planetary Sciences, Kyoto University, 606-8502, Japan \\ (Received February 22, 2005; Revised May 9, 2005; Accepted September 5, 2005)
}

\begin{abstract}
The Mid-Niigata earthquakes (mainshock: JMA M6.8, the largest aftershock: JMA M6.4) occurred on 23 October 2004 in the Shinano River fold and thrust zone, western margin of Northeast Japan. Two major Quaternary reverse fault systems, fault related to Higashiyama-Tamguiyama fold in western side and Muikamachi fault in eastern side, had already been mapped in aftershock area from the geological structure and tectonic morphostructure. These active fault and fold strike almost north-northeast-south-southwest. We investigated destructions of man-made structures and surface deformation using the releveling data by Geography Survey Institute. In turn, we examined about the origin of observed surface destructions from the compare with aftershock distribution. Our leveling and G.S.I leveling results indicate the deformation concordant with the Higashiyama-Tamugiyama fold and the offset along the a part of the northern half of Muikamachi fault. The vertical displacements are estimated to be ca. $70 \mathrm{~cm}$ and less than $20 \mathrm{~cm}$, respectively. The surface destructions were identified almost only along the Suwatoge flexure (correlated to the eastern limb of the Higashiyama-Tamugiyama fold), Tagawa anticline, Obiro fault and Muikamachi fault. The shortening amounts were estimated to be ca. $16 \mathrm{~cm}$ at the Suwatoge flexure, less than $2 \mathrm{~cm}$ at the Tagawa anticline and ca. $8 \mathrm{~cm}$ at the Muikamachi fault from the compressional destruction of man-made structure. The maximum vertical displacement and shortening was appeared at the bottom of Suwatoge flexure. The Suwatoge flexure is located onto the shallower extension of the row of aftershocks which was correlated to main shock earthquake. The Muikamachi fault is located near the shallower extension of the source fault of the largest aftershock. The stress regime inferred from the character of the observed surface destructions is concordant with the trend of geological structure and focal mechanism solutions. The small compressional destructions of man-made structures are byproducts created by buried faulting and folding. Thus, the Higashiyama-Tamugiyama folding structure grew in association with the buried faulting in the 2004 earthquake. Key words: Tectonic surface destruction, active fold, buried fault, aftershock distribution.
\end{abstract}

\section{Introduction}

The 23 October 2004 Mid-Niigata earthquakes (M6.8 in JMA scale for main shock) occurred in and around north Uonuma and south Higashiyama hills, the eastern region of the Shinano River fold and thrust zone abbreviated to S.F.T.Z in Fig. 1. The earthquake had seismic intensity of 7, which is the largest class of intensity in Japanese Meteorological scale, and the acceleration of 1722 gal at Kawaguchi Town, and it brought severe damage with landslides in and around hills.

The Japan Meteorological Agency and National Institute Earthquake Disaster gave us the information on source parameters with roughly northeast strike and reverse fault type. The focal mechanism solutions of 2004 major earthquakes are concordant with trends of pre-existing fold axis and active reverse fault. The hypocenters for main shock and aftershocks were relocated approximately $4.5 \mathrm{~km}$ to west-northwest of initially the reported hypocenters by the analysis of the temporal seismic observation data for five days after an earthquake (Sakai et al., 2005) and by the

Copyright (c) The Society of Geomagnetism and Earth, Planetary and Space Sciences (SGEPSS); The Seismological Society of Japan; The Volcanological Society of Japan; The Geodetic Society of Japan; The Japanese Society for Planetary Sciences; TERRAPUB. analysis of seismic data obtained from 100th temporal and teleseismic stations for one month (e.g.; Okada et al., 2005; Shibutani et al., 2005). The Mid-Niigata earthquake event was followed by highly prominent aftershock activity, with three major aftershocks of M6.0 or greater on the 23rd, and M6.1 on the 27th (Fig. 1).

The aftershock region is located in one of areas that the active folding structure was suggested first by the leveling survey, tectonic geomorphology and structural geology (Otsuka, 1942; Shirai, 1967; Nakamura and Ota, 1968; Ota, 1969; Mizoue et al., 1980, 1982; Kim, 2001, 2004). According to the restored deformation of geological structure in the S.F.T.Z, the shortening amount and the ratio of strain release were estimated to be about $20 \mathrm{~km}$ (Ikeda, 2002) and approximately $14 \%$ at least since Pliocene (Sato, 1994). The analysis of geodetic data, G.P.S., recently shows that the S.F.T.Z has large contractive strain rate of about $2.0 \mathrm{ppm} / \mathrm{yr}$ along the eastern margin of Sea of Japan (Sagiya et al., 2000). The Uonuma hills have a vertical slip rate of $2.0 \mathrm{~m} / \mathrm{kyr}$ in the maximum (Kim, 2001, 2004). The Mid-Niigata earthquake area is located in one of most active tectonic zone in Japan as stated above. However there had been unknown historical earthquake of greater magnitude than that of the 2004 earthquake at least after Edo- 


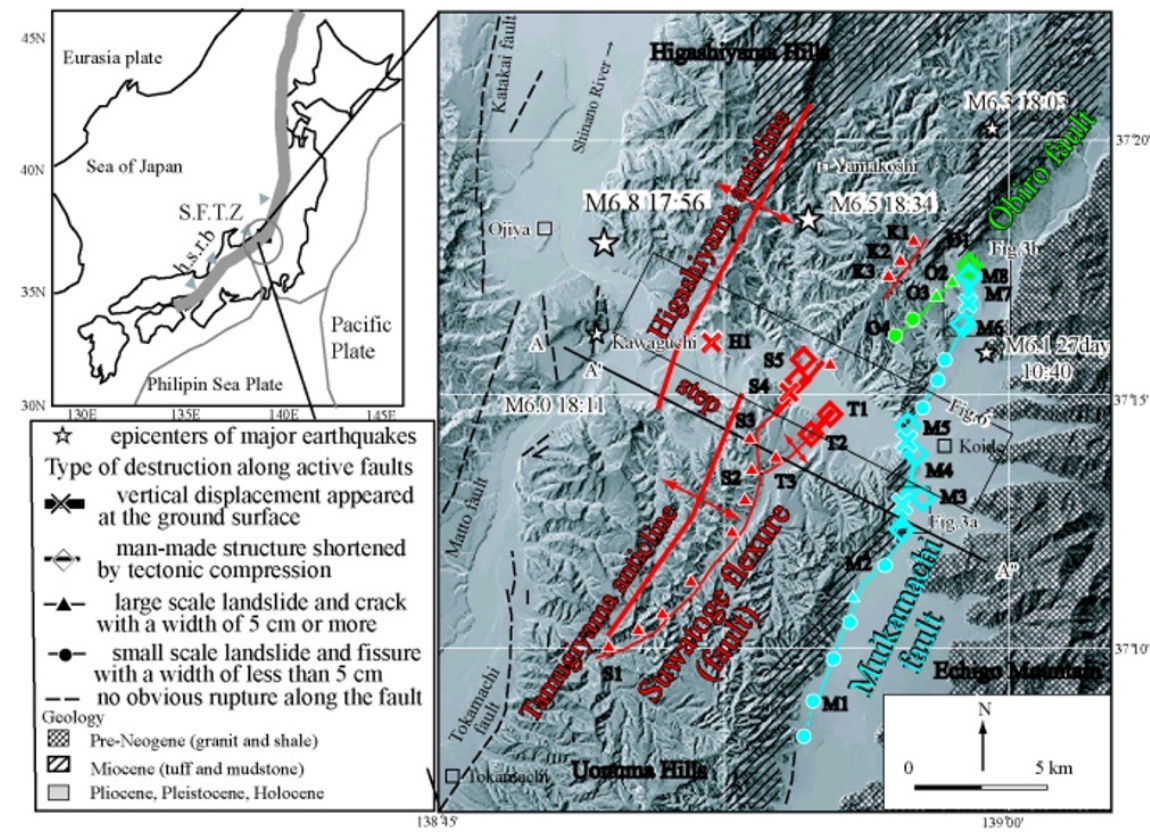

Fig. 1. Distribution of the surface destructions in the 2004 Mid-Niigata earthquake area Red color line and symbols demonstrates surface destructions in and around Higashiyama-Tamugiyama fold. Blue color line and symbols are surface destructions along Muikamachi fault. Green color indicates destructions along the Obiro fault. Epicenter is based on the analysis by Okada et al. (2005). Magnitude of earthquakes is based on the Japan Meteorological Agency. S.F.T.Z: Shinanogawa fold and thrust zone. h.s.r.b: the belt of high strain rate.

era (Namegaya et al., 2005). According to Mizoue et al. (1982), a folding structure near Ojiya has been formed by aseismic blind thrusting occasionally in association with the activity of micro earthquake swarm. Thus, the observation study is poor on the relationship between the formation of folding structure and earthquake activity.

We started field investigations on surface rupture and surface deformation from the early morning on October 25. The purpose of present study is to examine about the formation origin of observed surface destruction and surface deformation comparing with source fault inferred from aftershock observation. This paper contributes for identifying the active fault which caused the 2004 earthquake.

\section{Method}

We looked for visual evidence that is locality, geometry and offset direction for surface rupture and compressive destruction in man-made structures such as roads, waterways, concreted drain mouth, field and so on. The fieldwork area is limited in the region to access except Yamakoshi and Ojiya where our entry was forbidden. The surface rupture is identified as a fault that the source fault broke the earth's surface. The earthquake magnitude, however, is marginal to produce distinguishable surface rupture (e.g. Shimazaki, 1986). Then, we noticed to distinguish the tectonic surface destruction from the fissure and crack by ground motion and landslide. The surface destructions were classified into five groups: 1. surface deformation with vertical displacement, 2. compressive destruction of man-made structure, 3 . large scale landslide for the entire scarp collapsing and wide cracks, 4. relatively small landslide and narrow cracks, and 5. no obvious rupture along the fault (Fig. 1).

The observed compressive destruction is quite small as centimeter order. At the 2000 Tottori-ken Seibu earthquake in west Japan, the distribution of the small destructions of man-made structures shows the peculiar pattern to strike slip fault zone (Fusejima et al., 2001). The compressive destruction of man-made structure indicates a local stress regime, and it is available for the examination of surface break. Present study examines about the origin of surface destruction from the compare of the geological structure, aftershock distribution and releveling data.

\section{Active Fault and Active Fold}

In the aftershock area, the Muikamachi fault (Watanabe et al., 2001; Kim, 2001, 2004) and the Obiro fault (Watanabe et al., 2001) had been mapped along the eastern margin of Uonuma hills (Fig. 1). In the hills, the Suwatoge flexure had been mapped as the Quaternary fault (Yanagisawa et al., 1986; Kim, 2004). The Obiro strikes in sub-parallel to the Muikamachi fault (Fig. 1). The surface length of the Muikamachi fault is estimated to be about $42 \mathrm{~km}$. The cumulative displacement of northern Muikamachi fault is smaller than that of southern half, that is, as large as 1.6$2.0 \mathrm{~m} / \mathrm{kyr}$ at a southern part and as small as $0.8-1.3 \mathrm{~m} / \mathrm{kyr}$ at a northern part (Kim, 2001, 2004). The northern half of the Muikamachi fault is involved in the 2004 earthquake area. The Suwatoge flexure strikes northeast-southwest and $1.5 \mathrm{~km}-5.0 \mathrm{~km}$ to the west of the Muikamachi fault. The Suwatoge flexure accommodates the uplift and subsidence by high slip rate of ca. $1.0 \mathrm{~m} / \mathrm{kyr}$ (Kim, 2001, 2004). The flexure length is estimated to be more than $10 \mathrm{~km}$. These faults are estimated to be all west dipping reverse faults based on the geological context.

Figure 2 shows the geological cross section in the vicinity of epicenter. The geological structure is mainly classified to two groups between west side and east side based on the geological context, the Higashiyama-Tamugiyama 

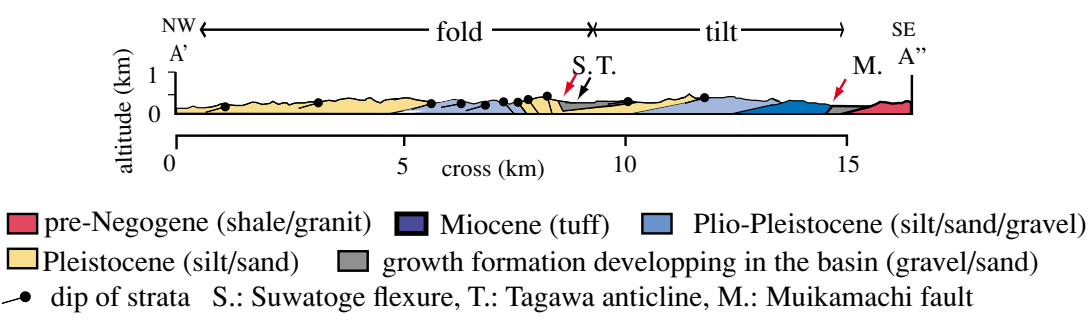

Fig. 2. The east-west geological section of the Uonuma hills Section $\mathrm{A}^{\prime}-\mathrm{A}^{\prime \prime}$ is shown in Fig. 1. Geological structure is modified from Yanagisawa et al. (1986) and Kim (2004).

folding structure and the Muikamachi fault related to tilting structure. These active structures roughly strike northeastsouthwest. Near Kawaguchi of the epicenter, anticlines step. The Tamugiyama fold and Higashiyama fold have an individual anticlinorium structure respectively. The geological complexity is different between respect fold structures. Tamugiyama anticline has an asymmetrical structure, in which beds dip between 50-80 degrees east in the eastern limb, and 15-20 degrees west in the western limb. This steep slope belt of eastern limb is authorized as Suwatoge flexure (Fig. 2; Yanagisawa et al., 1986; Kim, 2004). A quite small scale anticline, Tagawa anticline, strikes near about $2 \mathrm{~km}$ to the east of Suwatoge flexure (Fig. 1; between localities T1 and T2). Beds dip 1 degrees or less both east and west. In the Higashiyama hills, on the other hand, there are at least four traces of mapped short anticlines and active faults, which have $1 \mathrm{~km}$ to $10 \mathrm{~km}$ long. The Obiro fault is one of those, with a length of only $5 \mathrm{~km}$. The Obiro fault strikes on the northern extension of Tagawa anticline and $1.5 \mathrm{~km}$ to the east of the Suwatoge flexure. In turn, Muikamachi fault divides the Uonuma hills and the Muikamachi fault. The Uonuma hills have been tilted 10 degrees to 20 degrees to the west. Thus, there are two mountainous ridges, the Higashiyama-Tamugiyama anticlinal ridge and the monoclinal ridge related to Muikamachi fault, in the Uonuma hills (Figs. 1 and 2).

In the aftershock area, Neogene-Quaternay sedimentary stratum thickly overlaps on the Miocene tuff rock. The Miocene is appeared at the major axis of the Higashiyama anticline and along the Muikamachi fault (Fig. 1). The seismic reflective section, which was obtained by the oil company, images the west-dipping subsurface geological structure, and the thickness of Neogene-Quaternary sedimentary stratum is estimated to be about $6 \mathrm{~km}$ (Sato and Kato, 2005). The mountainous ridges are eroded in association with the uplifting, and the eroded sediments develop as the syntectonic strata in the western flank of mountainous ridges and as the tectonic growth strata in the Muikamachi basin (Kim, 2004). The Echigo Mountain and Muikamachi Basin are composed of pre-Neogene rocks (Figs. 1 and 2). Such geological structure affects focus determination.

\section{Surface Destructions and Geological Structure}

The west-side-up of surface fault and compressional destructions of man-made structures were appeared almost only along the pre-existing active fault. The horizontal compressive axis approximately shows the northwestsoutheast direction, which of direction is concordant with trend of pre-existing fault and major focal mechanism solution. We first describe our observations for the Muikamachi fault with obvious surface fault rupture, and then consider the Obiro fault and Suwatoge flexure.

\subsection{Muikamachi fault}

Surface fault were found at two localities M3 and M7 along the northern half of Muikamachi fault (Fig. 1; Suzuki et al., 2004 for M3; Maruyama et al., 2005 for M7). Both sites, which the fault ruptures emerged, is located at or near the boundary of basin Holocene sedimentary strata and Miocene tuff rock in the hills. Compressive destructions of the man-made structures intermittently are appeared only along and near the surface fault rupture (Fig. 1; localities M3, M4, M7 and M8). The distributional range reaches $12 \mathrm{~km}$ long in north-south. There are minor impression cracks with the width below several centimeters along the Muikamachi fault between M1 and M8, The locality M1 is located at the southern margin of observed aftershock.

4.1.1 Vertical displacement The west-side-up of offset has a continuous length of a little more than $100 \mathrm{~m}$, which was appeared on the lawn garden of a strongly-built house, rice paddy field, paved road and a concrete waterway at the locality M3 (Fig. 3(a)). These man-made structures were constructed on the flood plain, which was formed along the eastern margin of Uonuma hills. The vertical displacement is determined to be ca. $20 \mathrm{~cm}$ in the maximum from seven cross sections, those were measured using the total station. A typical profile $\mathrm{a}-\mathrm{a}^{\prime}$ in those sections is shown in Fig. 3. The cross sections show the compressive deformation with the bulge and the flexure, which are peculiar topography as a reverse fault. The west-ward dipping reverse fault was actually seen in the field path and the concrete structure (Fig. 4).

The flexure scarp was identified from the difference of dry and wet conditions of rice paddy along the Wada River (Fig. 1; locality M7, Maruyama et al., 2005). The length and the vertical displacement of 2004 surface fault is measured ca. $500 \mathrm{~m}$ and $10 \mathrm{~cm}$, respectively (Fig. 3(b); profile $\left.b-b^{\prime}\right)$. The strike is different between the pre-existing Muikamachi fault and the observed 2004 surface fault rupture, those strike, $\mathrm{N} 10^{\circ} \mathrm{E}$ and $\mathrm{N} 10^{\circ} \mathrm{W}$ to $\mathrm{N} 30^{\circ} \mathrm{W}$ respectively. The strike is harmony with the geological structure, and surface fault trace follows the northeastern margin of hill. Therefore the observed 2004 surface fault constitutes a northern trace of already known Muikamachi fault. At a joint, locality M6, between the 2004 fault and the preexisting fault, a deflection of drainage pipe is appeared. It probably occurred in the compression axis of southeast 


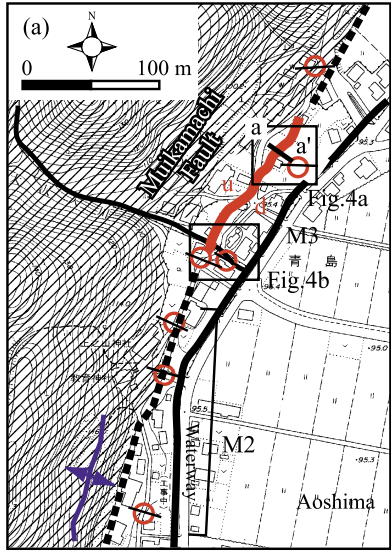

The topographic maps of (a) and (b) were graphy Survey Institute, respectively.

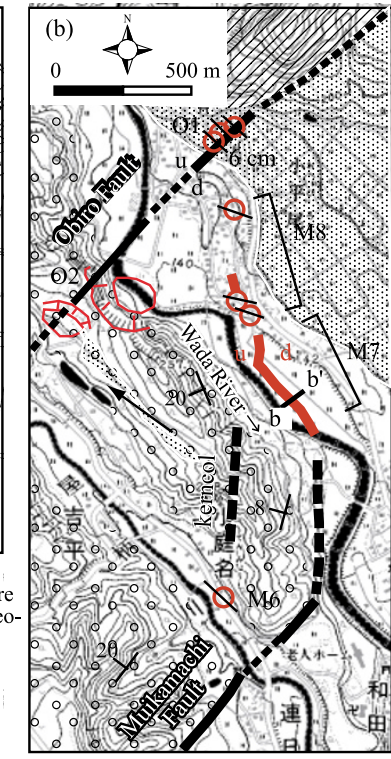

Explanatory

QA Miocene (tuff)

${ }^{\circ}$ 。 Plio-Pleistocene (sand and silt)

Pleistocene (gravel and sand) (terrace deposits)

Holocene (gravel and sand) (terrace and flood plain deposits)

u fault offset appeared at the ground surface shortening deformations

Q of the conrete and asphalt (The black line within a red circle indicates the compressive axisis.)

open crack and fissure

pre-existing fault (The dotted thin line indicates the unclear fault)

inferred fault after earthquake

${ }^{20} y$ strike and dip of strata

tilting inferred from the terrace deformation before earthquake

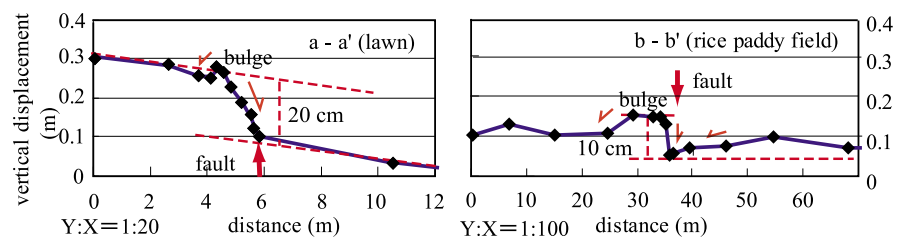

Fig. 3. Distribution and displacement of surface faults appeared along the Muikamachi fault Map areas are shown in Fig. 1.

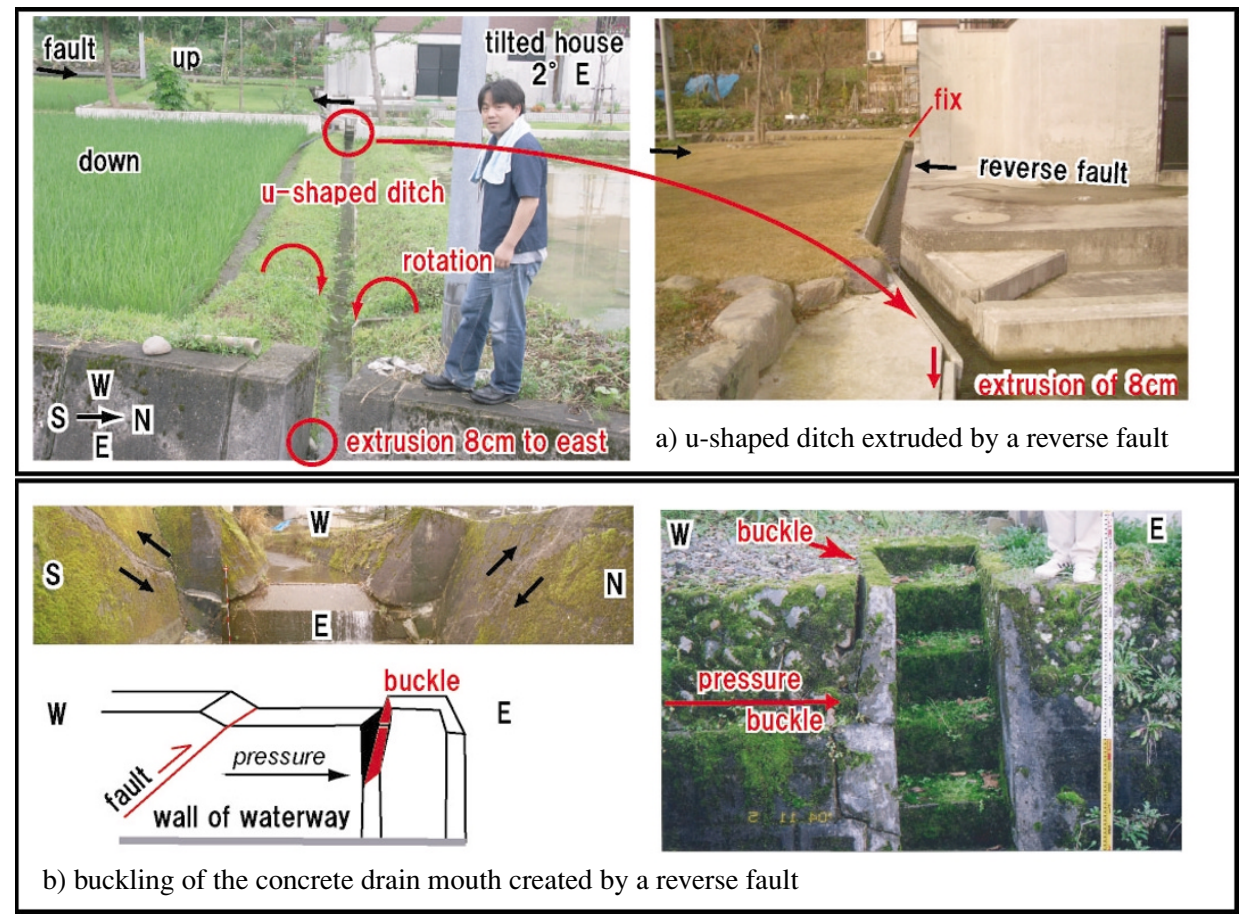

Fig. 4. Example of man-made structures along the Muikamachi fault destructed by tectonic compression Localities are shown in Fig. 3(a).

east-northwest west from the direction of pipe line. The shallow seismic reflection survey across locality M6 delineated the west-ward dipping reverse fault (Kato, N. et al., 2005; Sato and Kato, 2005). In turn, the buckles of asphalt and concrete are intermittently followed from north of surface fault rupture until locality $\mathrm{O} 1$ along the Obiro fault
(Maruyama et al., 2005). Although we can not seriously measure the shortening amount, it may be less than several centimeters from the compressive shape of man-made structures.

4.1.2 Shortening It depends both on their rigidity and shape, whether a man-made structure destructs or not. 

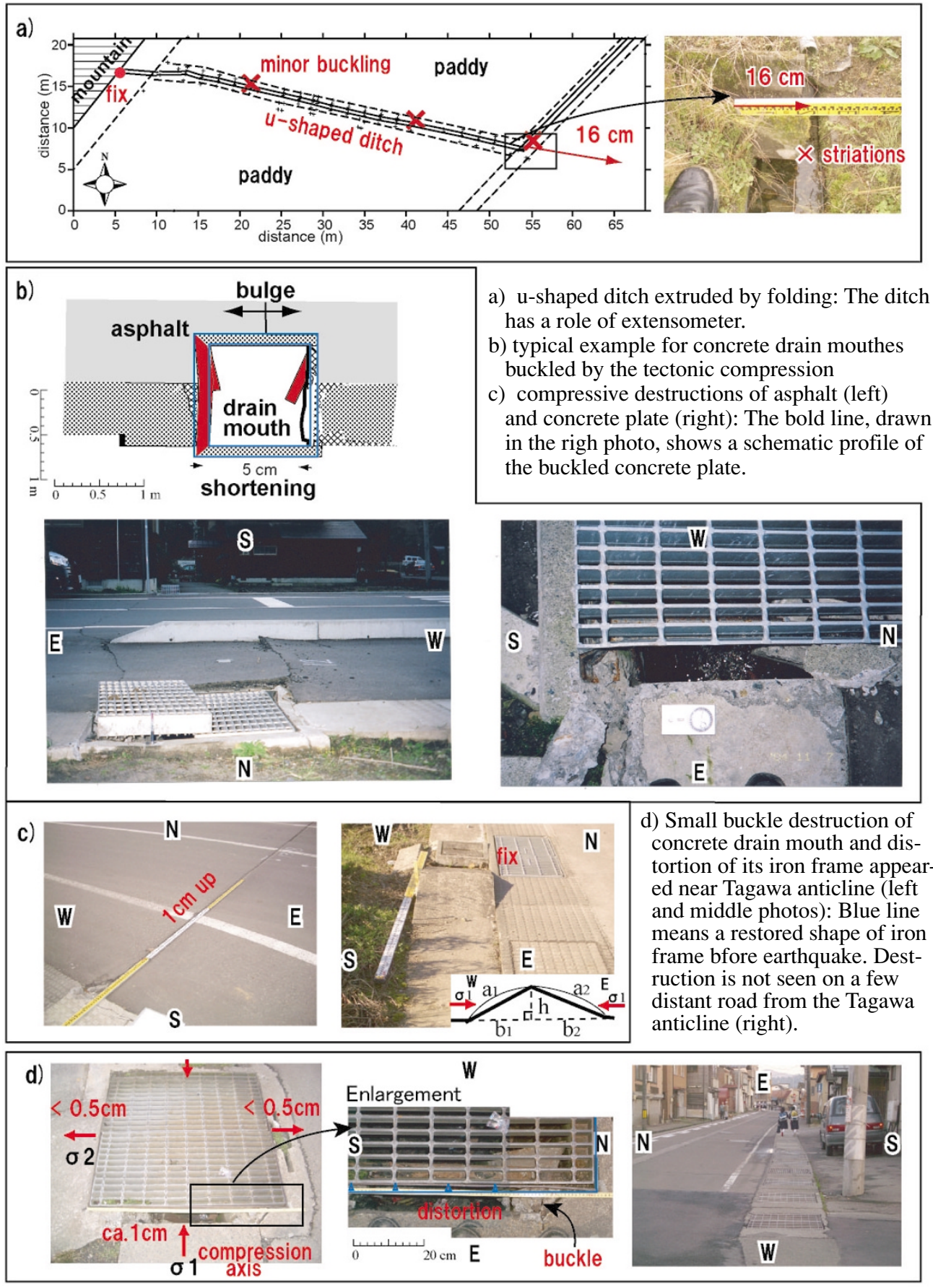

Fig. 5. Example of compressive destructions of man-made structures appeared along the Suwatoge flexure and near the Tagawa anticline The broken man-made structures, seen in (a), (b) and (c), were appeared at locality S4, the bottom of Suwatoge flexure. (d) is the small destruction appeared at locality T1 in and/or around Tagawa minor anticline. The localities S4 and T1 are shown in Figs. 1 and 6(a).

The observed man-made structures in the aftershock area are classified into mainly two types; the concrete u-shaped ditch and the concrete drain mouth seen along the paved asphalt road.

A u-shaped ditch, which was constructed between lawn garden and house ${ }^{1}$, crosses the surface fault rupture almost at 90 degrees (Fig. 4(a)). The ditch is made of concrete

\footnotetext{
${ }^{1}$ According to a resident of the house seen in Fig. 4(a), the door became the state left open by the maximum aftershock, and the house declined greatly to the east. It was thought that only a few inclined at the time of the main shock.
}

segments with $2 \mathrm{~m}$ length, $40 \mathrm{~cm}$ width and $30 \mathrm{~cm}$ depth, and the entire length is ca. $35 \mathrm{~m}$. A section of u-shaped ditch is entirely pushed $8 \mathrm{~cm}$ to the east, and the concrete segments are buckled in the footwall side. Neither the opening crack which deserves the amount of extrusion, nor the trace of liquefaction is found around the ditch. When the block of Uonuma hills thrusts up to the block of flood plain, the foundation had contracted. Thus, the extrusion of ditch indicates a shortening of ground foundation and the u-shaped ditch has a role as an extensometer.

There is a waterway across active fault $200 \mathrm{~m}$ to the 

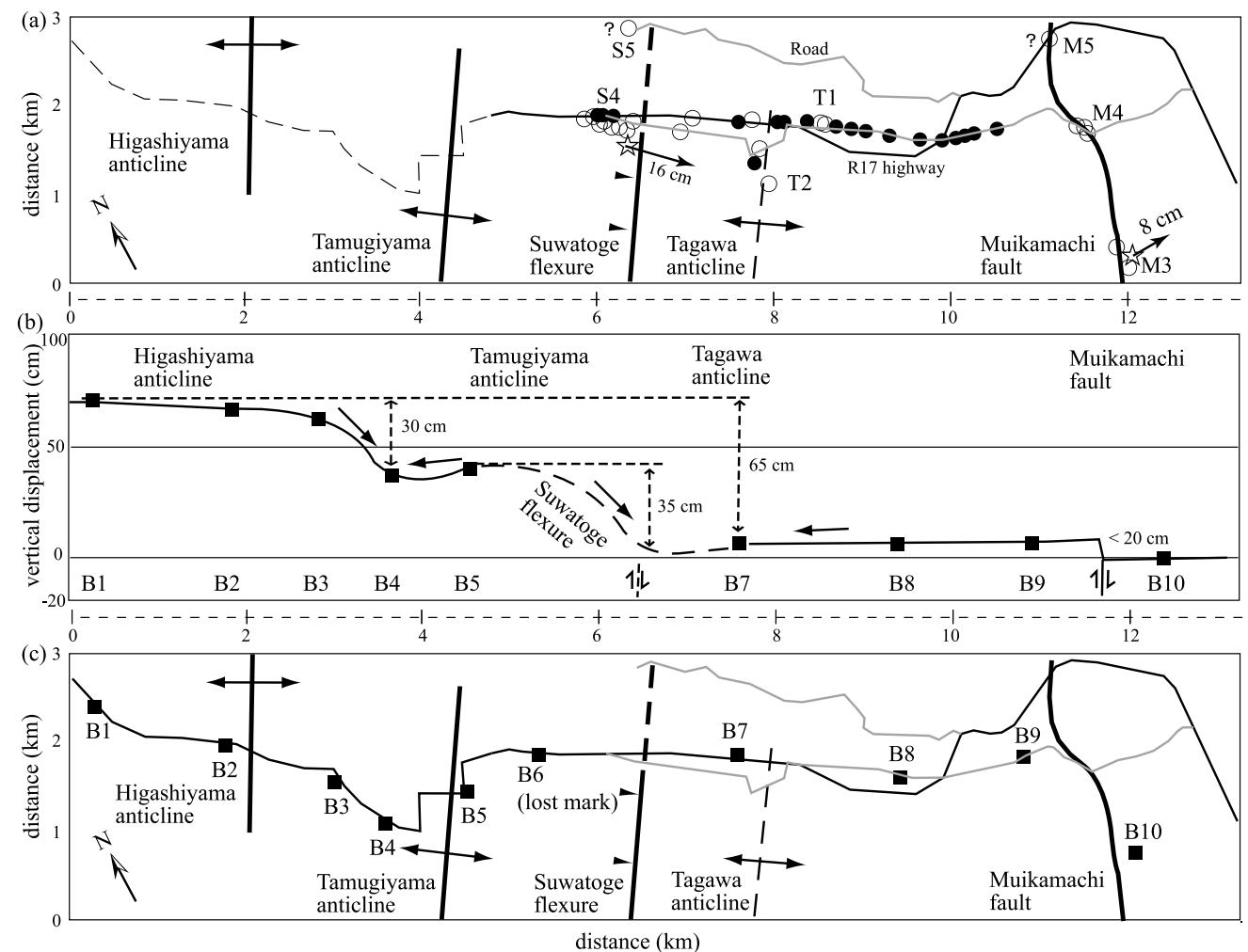

Fig. 6. Distribution of surface destructions by the compression (a) and vertical displacement derived from leveling data (b) The area is across the epicenter of main shock and shown in Fig. 1. (a) Open circles: destruction of mainly concrete drain mouths and asphalt road; Star marks with the arrow: shortening amount derived from the extrusion of u-shaped ditch; Black circles: unclear destruction of drain mouths; Non mark on the road and highway: unclear destruction; Dashed line: un-investigation highway (b) the vertical displacement is estimated from the difference between 2001.9-1996.9 leveling data and 2004.11-2004.12 leveling data, which were obtained by Geography Survey Japan. The location of bench marks, black squares, is shown in (c).

south from the u-ditch (Fig. 3(a)). The waterway is compressed by reverse faulting, hence a concrete drain mouth equipped in the footwall side receive the buckle destruction (Fig. 4(b)). The obvious destruction is considered to generate in the existing weak place. The fault plane dips about 30 degrees to the west. It is hard to determine shortening amount from the destructed shape. Such compressive destruction is not here and there, but exists along the preexisting Muikamachi fault.

\subsection{Obiro fault}

The buckle destructions are appeared in the asphalt road and its concrete frame at one locality of the northern region along the Obiro fault (locality O1; Fig. 1). These compressive destructions are located on the east facing fault scarp which crosses the lower terrace along the Wada River (Fig. 3(b)). The open fissure with a width of less than 2 mm strikes along the fault scarp. Therefore an influence of landslide cannot necessarily be denied. The vertical offset was estimated to be ca. $30 \mathrm{~cm}$ from the auto leveling carried out on the asphalt road (Suzuki et al., 2004). At the major part of Obiro fault, the landslide and the open crack are observed almost only along the fault trace (Fig. 1; localities $\mathrm{O} 2, \mathrm{O} 3$ and $\mathrm{O} 4)$. There may be unknown surface modification by tectonic compression. The damage is relatively small around the active fault. The large scale of landslide is conspicuous at the western side of Suwatoge flexure which strikes $1.5 \mathrm{~km}$ to the west of Obiro fault (Fig. 1; localities $\mathrm{K} 1, \mathrm{~K} 2$ and $\mathrm{K} 3$ ).

\subsection{Suwatoge flexure and its related folds}

The compressive surface destructions are seen at locality $\mathrm{H} 1$ in and at localities S4 along the Higashiyama and Tamugiyama folds (Figs. 1 and 5). The boundary of uplift and subsidence is recognized at the eastern bottoms of Tamugiyama anticline and Higashiyama anticline (Fig. 6). The eastern limb of anticlines is called as the Suwatoge flexure (Yanagisawa et al., 1986; Kim, 2004). The southern and northern regions of Suwatoge flexure are prominent in landslides, and it is hard to distinguish the tectonic surface destruction (Fig. 1; localities S1, S2, S3, K1, K2, K3 and $\mathrm{T} 1)$.

4.3.1 Compressive destructions At locality S4 on the Suwatoge flexure, a u-shaped concrete ditch of $49 \mathrm{~m}$ long strikes $\mathrm{N} 70^{\circ} \mathrm{W}$ at the paddy field (Figs. 5(a) and 6(a)). Paddy field is cultivated on the alluvial plane. A u-shaped ditch is apparently pushed ca. $16 \mathrm{~cm}$ to the east. The fine striations are carved into the concrete. The open crack and liquefaction are almost not seen in and around concrete ditch. Thus an extrusion of ditch was considerably created by the shortening of the ground.

At localities S4, minor buckle destructions were observed in ten concrete drain mouths and asphalt road (Figs. 5(b) and (c)). Their destructions were formed in the northwestsoutheast compressive stress regime from the destruction shape. One of the concrete drain mouths was squashed ca. $5 \mathrm{~cm}$ (Fig. 5(b)). In immediately near on the same road, the asphalt was uplifted $1 \mathrm{~cm}$ and the concrete plate was 
buckled (Fig. 5(c)). The buckle shape of concrete plate has almost a typical triangle (Fig. 5(c); right photo). The length a1 and $\mathrm{a} 2$ of the oblique side of the buckled plate was $53 \mathrm{~cm}$ and $58 \mathrm{~cm}$, respectively. The height was estimated to be $9 \mathrm{~cm}$ to $12 \mathrm{~cm}$ and the length of $\mathrm{b}$ of the base side was measured to be $102 \mathrm{~cm}$ to $117 \mathrm{~cm}$. The strict values were not obtained. The amount of shortenings of this point estimated from this plate is less than several $\mathrm{cm}$ from a trigonometric ratio. There may be open crack and fissure on the road. However, a larger opening crack than the amount of compression is not observed by our investigation at least. Thus, the total shortening may become $5 \mathrm{~cm}$ or more from the number of buckle destructions. At locality S5, the pipe, buried beneath the road, was deflected with the apparently height of about $10 \mathrm{~cm}$ by compression (Figs. 1 and 6(a)). The S5 point is located near the margin of mountain. Therefore it is difficult to distinguish whether the observed destruction is by a tectonic origin or not.

4.3.2 Vertical displacement The bench marks for leveling have already been deployed at interval of about $2 \mathrm{~km}$ along the national highway Route 17. The distribution of benchmarks and the result of releveling are shown in Figs. 6(b) and (c). Benchmarks here are called as B1, B2 ... $\mathrm{B} 10$ in order from west to east. Route 17 strikes almost a direction perpendicular to the anticlines and crosses the step zone of Higashiyama anticline and Tamugiyama anticline.

The maximum uplift is appeared at B1 and B2 exactly on the Higashiyama anticline. The uplift amount was measured to be ca. $70 \mathrm{~cm}$ by G.S.I. The Tamugiyama anticline has an uplift of $40 \mathrm{~cm}$ on the locality B5. The synclinal axis strikes between Higashiyama anticline and Tamugiyama anticline, where it has an uplift of $38 \mathrm{~cm}$ for B4. The syncline has an asymmetrical folding structure that the east wing of Higashiyama has a steep slope and the west wing of Tamugiyama has a gentle slope (Fig. 6(b)). The vertical displacement on the eastern limb of the Higashiayama anticline is estimated to be at least ca. $30 \mathrm{~cm}$ from the difference of vertical movements derived between B1 and B4.

The boundary of uplift and subsidence is recognized at the eastern flank of Tamugiyama anticline between B5 and B7. It is hard to point out the boundary of upheaval and subsidence due to the damage of benchmark for locality B6. The compressive ruptures of man-made structures are appeared at the bottom of Suwatoge flexure, locality S4, between B5 and B7 (Fig. 6(a)). The vertical displacement is estimated to be at least ca. $35 \mathrm{~cm}$ from the difference between B5 and B7 releveling data. The B7, B8 and B9 in the footwall side have uplift of only 3 to $4 \mathrm{~cm}$ by the Muikamachi fault.

\subsection{Tagawa anticline}

The quite small buckles are seen in five concrete drain mouths at localities between $\mathrm{T} 1$ and $\mathrm{T} 2$. This weak zone is located almost along the Tagawa anticline (Figs. 5(d) and 6(a)). The observed shortening is only $2 \mathrm{~cm}$ in the maximum. Such compressive destruction is not here and there. If it separates from anticline presumed from geological structure investigation, destruction of a structure will seldom be seen (Fig. 5(d)). There is not recognized vertical offset along this weak zone between the leveling benchmark B7 and B8 (Figs. 6(a) and (c)).

\section{Discussion}

The co-seismic folding deformation was derived on the Higashiyama-Tamugiyama fold from the releveling data. In addition, a lot of minor compressive destructions were appeared in man-made structures which were constructed at the bottom of eastern limb of anticlines, at the Tagawa anticline and Obiro fault. Along the Muikamachi fault, the surface fault with vertical offsets was identified. The origin of observed surface ruptures is discussed as follows.

\subsection{Active fault and aftershock distribution}

The location of aftershock hypocenters is welldetermined by different techniques with different data sets taking into consideration of the regional seismic velocity structure (Aoki et al., 2005; Hirata et al., 2005; Kato, A. et al., 2005a, b; Korenaga et al., 2005; Okada et al., 2005; Sakai et al., 2005; Shibutani et al., 2005). The relocated results are almost similar respectively. The velocity of seismic $P$ and $\mathrm{S}$ waves is different between the western region and the eastern region. The lower velocity structure reflects the thickly accumulated Neogene-Quaternay sedimentary strata (e.g.: Kato, A. et al., 2005a; Okada et al., 2005; Sakai et al., 2005; Shibutani et al., 2005). The origin of observed surface deformations is addressed from compare of the aftershock distribution and the active fault. Figure 7 shows the well-relocated hypocenters by Okada et al. (2005).

The double-difference tomography, which was used not only absolute travel times but also travel time differences between nearby events at each station in 60th temporal and the routine seismic stations, images high resolution 3D seismic P-wave velocity structure and the better settled distribution of hypocenters (Okada et al., 2005). The Higashiyama and Tamugiyama folds are appeared in the layer with the lower velocity. The Muikamachi fault is recognized in the layer with higher velocity (Fig. 7).

The fault plane of main shock, which is inferred from the group of aftershocks, lie roughly along the vicinity of the boundary between low velocity and high velocity (Kato, A.

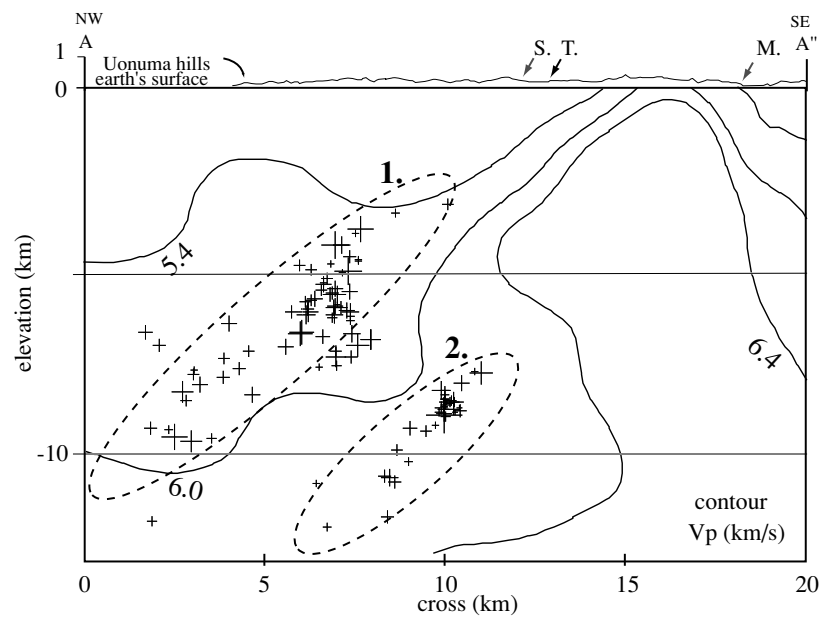

Fig. 7. Tectonic surface destruction and hypocenters of aftershocks Cross A-A" is shown in the Fig. 1. S: Suwatoge flexure, T: Tagawa anticline, M: Muikamachi fault. Dotted circles 1 and 2 show groups of aftershocks correlated to fault planes of main shock and largest aftershock, respectively. The aftershock distribution and contour of P-wave velocity are based on Okada et al. (2005). 
Table 1. The nature of observed surface displacements.

\begin{tabular}{|c|c|c|c|c|c|c|}
\hline \multirow{2}{*}{ Name of fault system } & \multirow{2}{*}{$\begin{array}{l}\text { Upthrown } \\
\text { side }\end{array}$} & \multicolumn{2}{|c|}{ displacement $(\mathrm{cm})$} & \multirow{2}{*}{$(\# 2)$ reference } & \multirow{2}{*}{ (\#3)locality } & \multirow{2}{*}{ fault type } \\
\hline & & vertical & horizontal & & & \\
\hline $\begin{array}{l}\text { Fault related to Higashiyama- } \\
\text { Tamugiyama fold }\end{array}$ & & 65 & & leveling line (v) & & surface \\
\hline $\begin{array}{r}\text { Higashiyama anticline } \\
\text { (eastern limb) }\end{array}$ & NW & 30 & & leveling line (v) & H1 & $\begin{array}{l}\text { deformation } \\
\text { formed by a } \\
\text { subsurface }\end{array}$ \\
\hline $\begin{array}{r}\text { Tamugiyama anticline } \\
\text { (Suwatoge flexure, east limb) }\end{array}$ & NW & 35 & 16 & $\begin{array}{l}\text { leveling line }(\mathrm{v}) \\
\mathrm{u} \text {-shaped ditch }(\mathrm{h})\end{array}$ & S4 & source faulting \\
\hline Tagawa anticline & & & 2 & drain mouth & $\mathrm{T} 1$ & \\
\hline Obiro fault (major part) & & & & & $\mathrm{O} 2-\mathrm{O} 4$ & \\
\hline Muikamachi fault & & 20 & & & & \\
\hline northern half of segment & W & 20 & 8 & $\begin{array}{c}\text { lawn (v) } \\
\text { u-shaped ditch (h) }\end{array}$ & M3 & $\begin{array}{l}\text { surface fault by } \\
\text { an induction of } \\
\text { shock or/and }\end{array}$ \\
\hline northern half of segment & W & 10 & & rice paddy (v) & M7 & displacement \\
\hline Obiro fault (one part) & NW & $(\# 1) 30$ & & paved road & $\mathrm{O} 1$ & \\
\hline
\end{tabular}

\#1: Data of displacement is based on Suzuki et al. (2004).

$\# 2$ : (v) and (h) are the reference of vertical displacement and horizontal displacement, respectively.

\#3:locality is shown in Fig. 1.

et al., 2005; Korenaga et al., 2005; Okada et al., 2005). The estimated fault plane has a west-dipping blind reverse fault with a high angle of 50 to 60 degrees. The aftershocks are recognized at depth of about $3 \mathrm{~km}$ or deeper area beneath the Higashiyama-Tamugiyama fold. The Suwatoge flexure, on which the largest vertical movement was derived in the 2004 earthquake sequence, seems to exist onto an upward extension of the mainshock fault plane (Fig. 7; Table 1).

The fault plane of the largest aftershock, which was inferred from the group of aftershocks, is found about $5 \mathrm{~km}$ to the east from the main shock. In addition, it is recognized in the $5 \mathrm{~km}$ or deeper area beneath the earth's surface (Fig. 7). The largest aftershock clearly occurred in a high velocity domain (Kato, N. et al., 2005; Korenaga et al., 2005; Okada et al., 2005). The inferred seismic fault plane has a westdipping reverse fault. The Muikamachi fault seems to exist onto the shallower extension of this seismic fault plane.

The importance of aftershock observation here is enhanced by the assumption that the presumed source fault has not arrived at the earth's surface both for the main shock and the largest aftershock. The releveling data indicates that the Higashiyama-Tamugiyama fold is estimated to be the bend deformation which was formed at the earth's surface by the buried source fault. Then, the vertical offset along Muikamachi fault is the surface fault which was appeared in the place which is distant from a source faults for the main shock and aftershock. Near earth's surface, the Muikamachi fault with the west-side up offset is located at the boundary between the Quaternary basin sediments and Miocene tuff. Since the Muikamachi fault is the boundary of a substance, it is easy to rupture.

\subsection{Compressive minor destruction in man-made structure}

Present paper discusses about the origin of observed compressive minor destructions. The bottom of Suwatoge flexure, Tagawa anticline and Obiro fault are located at the concave side from geological structure (Figs. 1 and 2). The general statements on the interior deformation of folding structure are already suggested by Yeats (1986). Deforma-

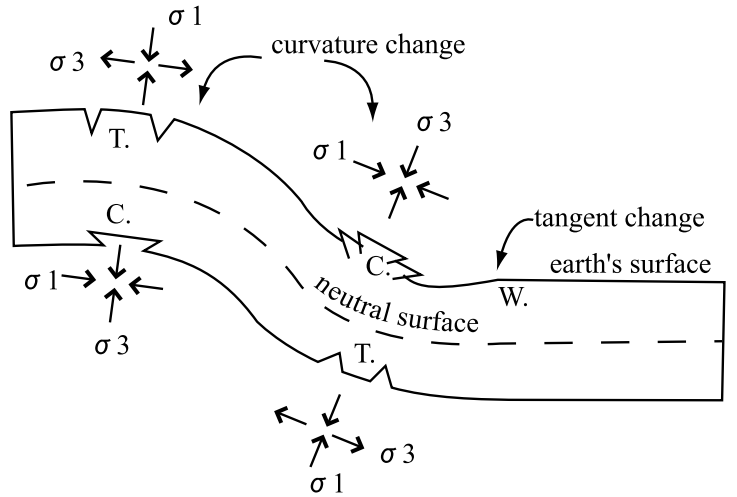

Fig. 8. Schema of bending moment destruction On the convex surface, the minimum principal compressive stress $(\sigma 3)$ is tangent to the plate surface but perpendicular to the axis of bending, whereas on the concave surface, the maximum principal compressive stress $(\sigma 1)$ has this orientation. Thus, the convex side is in tension (T.), whereas the concave side is in compression (C.). At the tangent change, earth surface becomes weak (W.) by local stress. Basic schematic diagram is based on Yeats (1986).

tion of a flexed layer can be treated as bending an elastic plate around a fold axis, because the regional folding structure has a fairly typical bend structure. If the plate is bent by equal and opposite moments applied to its ends, the convex side is lengthened and placed in tension, and the concave side is shortened and placed in compression (Fig. 8). The compression and tension of the sides are produced by a couple or bending moment. Between that portion of the plate in compression and that portion in tension at depth, there is a neutral surface on which there is neither compression nor tension.

Thus observed small destructions are probably created in the shallower layer from the neutral surface near earth's surface, and they are not capable of generating large earthquakes based on a model of the bending moment fault of Yeats (1986). This presumption is not contradictory to the result that the subsurface aftershock alignment has not ar- 
rived on the earth's surface (Kato, A. et al., 2005a, b; Okada et al., 2005; Shibutani et al., 2005). The observed surface destructions may be unconnected to the source fault at depth.

In addition to the model by Yeats (1986), the strain within a bent plate is approximately proportional to the distance from the neutral surface and inversely proportional to the radius of curvature of the plate. The bottom of Suwatoge flexure may be relatively located at the large portion of curvature change as syncline. The Tagawa anticline may be located at the tangent change. The origin of surface destruction above mention is one idea that was interpreted in an elastic model, therefore the examination based on experiment, analysis, and observation is required in the future.

\subsection{Geomorphic evaluation}

The nature of observed surface displacement is shown in Table 1. The step zone of Higashiyama and Tamugiyama folding structures has the vertical displacement of 65 $\mathrm{cm}$ at least. The displacement on the Higashiyama and Tamugiyama folding structure is 3 or more times than that of the Muikamachi fault. The amount of horizontal displacement on Suwatoge flexure is twice more than those of the Tagawa weak zone, Obiro fault and Muikamachi fault. Thus, the largest boundary between uplift and subsidence, in the 2004 Mid Niigata earthquake, was appeared at the bottom of Suwatoge flexure.

At depth, the maximum slip on the fault plane was seen near the hypocenter and was estimated to be $1.4 \mathrm{~m}$ to $3.8 \mathrm{~m}$ from the waveform inversion analysis using the near field data and teleseismic data (e.g.: Yamanaka, 2004; Asano and Iwata, 2005; Hikima and Koketsu, 2005; Honda et al., 2005; Mori and Somerville, 2005; Yagi, 2005). The fault slip was considerably dispersed in the folding deformation zone. A lot of minor faults are actually observed in the Quaternary and/or older sedimentary stratum.

The displacement of the Mid Niigata earthquake affects the development of geographical feature and growth of geological structure of this area. At last, we argue about the influence on the morphostructure by this earthquake based on the ratio of co-seismic displacement and cumulative displacement along the Muikamachi fault. The average recurrence interval of the earthquake is calculated from a slip rate and an amount of offset along the fault, when a uniform displacement and uniform repeat is assumed along the fault (Matsuda, 1975). Thus, the earthquake of M6.8 class is simulated to have occurred once in 250 to 375 years from the slip rate of 0.8 to $1.3 \mathrm{~m} / \mathrm{kyr}$, and the 2004 maximum offset amount of $20 \mathrm{~cm}$. But a historical earthquake as large as Mj6.8 class is not known in this area (Namegaya et al., 2005). This means that the characteristic earthquake, that is uniform slip and uniform repeat, is not realized at least along the Muikanachi fault. We need to assume co-and/or a-seismic movement which is different from the sense of recent earthquake for leading to the cumulative displacement along the Muikamachi fault.

\section{Conclusion}

The surface destructions of tectonic origin were identified along the pre-existing fault and fold by the field observation, which was carried out immediately after earthquake.
The surface destructions were generated roughly in the compression regime of northwest-southeast axis from the shape of broken man-made structures. Its trend is concordant with major focal mechanism solutions and trend of geological structure. The largest boundary between uplift and subsidence was identified at the bottom of Suwatoge flexure, which corresponds to the eastern limb of Higashiyama and Tamugiyama anticlines.

The Suwatoge flexure is located onto the shallower extension of the aftershock alignment correlated to main shock fault plane. The Muikamachi fault is located onto the shallower extension of the source fault corresponded to the largest aftershock. Thus, two reverse fault systems exist in the Mid Niigata earthquake area, those are, fault related to Higashiyama-Tamugiyama fold and Muikamachi fault. The folding structure grew in association with buried faulting in the 2004 earthquake sequence.

The surface fault with vertical offset is appeared along the northern half of Muikamachi fault. The surface fault is not visible to surface rupture that a source fault broke the ground surface from aftershock locations and geological context. The small compressive destructions of manmade structures are byproducts created by buried faulting and folding. The tectonic destruction along the Suwatoge flexure is considered to be a bending-moment destruction, which was generated by folding. The importance for tectonic surface destruction in seismic risk evaluations and geomorphic evaluations is in the fact that they emerged along the pre-existing fault and fold.

Acknowledgments. We are grateful for facilitates of investigation to the Niigata Prefecture and Uonuma Municipal office. The air photos and the leveling data, those were obtained by Geography Survey Institute, were used in this study. We could have the available discussion with members of Geology Survey of Japan and other research groups in the field survey. Dr. Walker, R. (Oxford Univ.), Dr. Okada, T. (Tohoku Univ.), Prof. Shimazaki, K. (Univ. of Tokyo), Prof. Ito, T. (Chiba Univ.) and Prof. Hirata, N. (Univ. of Tokyo) gave the significant information to revise the present study. The measurement was helped by Mr. Sugito, N. (Kyoto Univ.). We are grateful to Profs. Mori, J., Chigira, M., Shibutani, T., Iio, N., (Kyoto Univ.) and Lee, C.-T. (Taiwan, National Central University). Part of this study has been supported by the Grant-In-Aid for Scientific Research in 2004 (Project Number: 16200050, Head Investigator: A. Okada, Kyoto university).

\section{References}

Aoki, S., M. Nishi, K. Nakamura, T. Hashimoto, S. Yoshikawa, and H. M. Ito, Multi-planar structures in the aftershock distribution of the Mid Niigata prefecture Earthquake in 2004, Earth Planets Space, 57, 411416, 2005.

Asano, K. and T. Iwata, Source process of the 2004 Mid Niigata Prefecture earthquake estimated from the waveform inversion of strong motion records, 2005 Joint Meeting for Earth and Planetary Science, abstract, S079P-007, 2005 (in Japanese with English abstract).

Fusejima, Y., T. Yoshioka, K. Mizuno, M. Shishikura, R. Imura, T. Komatsubara, and T. Sasaki, Surface ruptures associated with the 2000 Tottori-ken Seibu earthquake, G.S.J. Annual Report on Active Fault and Paleoearthquake Researches, 1, 1-26, 2001 (in Japanese).

Hikima, K. and K. Koketsu, Source processes of the Mid Niigata Prefecture earthquakes in 2004 inferred from strong motion data, 2005 Joint Meeting for Earth and Planetary Science, abstract, S101-016, 2005 (in Japanese with English abstract).

Hirata, N., H. Sato, S. Sakai, A. Kato, and E. Kurashimo, Fault system of the 2004 Mid Niigata Prefecture Earthquake and its aftershocks, Landslides, 2, doi:10.1007/s10346-005-0050-8, 2005. 
Honda, R., S. Aoi, N. Morikawa, H. Sekiguchi, T. Kunugi, and H. Fujiwara, Ground motion and rupture process of the 2004 Mid Niigata Prefecture earthquake obtained from strong motion data of K-NET and KiK-net, Earth Planets Space, 57, 527-532, 2005.

Ikeda, Y., The origin and mechanism of active folding in Japan, Active Fault Research (Katsudanso Kenkyu), 22, 67-70, 2002 (in Japanese with English abstract).

Kato, A., E. Kurashimo, N. Hirata, T. Iwasaki, and T. Kanazawa, Imaging the source region of the 2004 Mid-Niigata prefecture earthquake and the evolution of a seismogenic thrust-related fold, Geophys. Res. Lett., doi: 10.1029/2005GL022366, 2005a.

Kato, A., S. Sakai, N. Hirata, E. Kurashimo, S. Nagai, T. Iidaka, T. Igarashi, Y. Yamanaka, S. Murotani, T. Kawamura, T. Iwasaki, and T. Kanazawa, Spatiotemporal variations of the aftershock distributions during one month after the occurrence of the 2004 mid-Niigata prefecture earthquake, Earth Planets Space, 57, 551-556, 2005 b.

Kato, N., T. Echigo, H. Sato, M. Tateishi, S. Ogino, S. Sakai, S. Toda, S. Koshiya, T. Ito, T. Toyoshima, T. Imaizumi, H. Kato, and S. Abe, Geologic fault model based on High-resolution seismic reflection profiling across the surface rupture associated with the 2004 Mid-Niigata Prefecture earthquake (M6.8), central Japan, Earth Planets Space, 57, 447-452, 2005.

Kim, H. Y., Active faults along the western margin of the Muikamachi Basin, central Japan, Quaternary Research (Daiyonki Kenkyu), 40, 161168, 2001 (in Japanese with English abstract).

Kim, H. Y., Relationship between the upheaval process of the Uonuma Hills and the cumulative nature of the Muikamachi fault, central Japan, Active Fault Research (Katsudanso Kenkyu) 24, 63-75, 2004 (in Japanese with English abstract).

Korenaga, M., S. Matsumoto, Y. Iio, T. Matsushima, K. Uehira, and T. Shibutani, Three dimensional velocity structure around aftershock area of the 2004 Niigata-ken Chuetsu Earthquake (M6.8) by the DoubleDifference tomography, Earth Planets Space, 57, 429-433, 2005.

Maruyama, T., Y. Fusejima, T. Yoshioka, Y. Awata, and T. Matsu'ura, Characteristics of surface rupture associated with the 2004 Mid Niigata Prefecture earthquake, central Japan and their seismotectonic implications, Earth Planets Space, 57, 521-526, 2005.

Matsuda, T., Magnitude and recurrence interval of earthquakes from a fault, J. Seis. Soc. Jap. (Zisin), 28, 269-283, 1975 (in Japanese with English abstract).

Mizoue, M., K. Nakamura, and S. Izutsuya, Mode of vertical crustal movements as deduced from the precise relevelings in the Ojiya active folding area, Niigata Prefectrure, Northeast Japan, Bull. Earthq. Res. Inst., 55, 199-224, 1980 (in Japanese with English abstract).

Mizoue, M., T. Yokota, and I. Nakamura, High angle reverse faulting in the interaxial zone of active folds in the inner belt of Northeast Japan, Bull. Earthq. Res. Inst., 57, 359-377, 1982 (in English with Japanese abstract).

Mori, J. and P. Somerville, 2004 Niigata-ken Chuetsu EarthquakeSeismology and strong ground motions, Earthquake Engineering Research Institute, 2005 (submitted).

Nakamura, K. and Y. Ota, Study of active fold in Japan, a review, Quaternary Research (Daiyonki Kenkyu), 7, 200-211, 1968 (in Japanese with English abstract).

Namegaya, Y., Y. Tsuji, and J. Ito, Detailed distributions of seismic intensities of the 1828 Bunsei Echigo-Sanjo and the 1751 Horeki EchigoTakada earthquakes, 2005 Joint Meeting for Earth and Planetary Science, abstract, J027-011, 2005 (in Japanese with English abstract).

Okada, T., N. Umino, T. Matsuzawa, J. Nakajima, N. Uchida, T.
Nakayama, S. Hirahara, T. Sato, S. Hori, T. Kono, Y. Yabe, K. Ariyoshi, S. Gamage, J. Shimizu, J. Suganomata, S. Kita, S. Yui, M. Arao, S Hondo, T. Mizukami, H. Tsushima, and T. Yaginuma, Aftershock distribution and 3D seismic velocity structure in and around the focal area of the 2004 mid Niigata earthquake obtained by applying doubledifference tomography to dense temporary seismic network data, Earth Planets Space, 57, 435-440, 2005.

Ota, Y., Crustal movements in the late Quaternary considered from the deformed terrace plains in northeastern Japan, Japanese J. Geol. Geophys., 40, 41-61, 1969.

Otsuka, Y., Active rock folding in Japan, Proc. Imp. Acad. Japan, 13, 7881, 1941 (in Japanese).

Sagiya, T., S. Miyazaki, and T. Tada, Continuous GPS array and presentday crustal deformation of Japan, PAGEOPH, 157, 2303-2322, 2000.

Sakai, S., N. Hirata, A. Kato, E. Kurashimo, T. Iwasaki, and T. Kanazawa, Multi-fault system of the 2004 Mid-Niigata Prefecture Earthquake and its aftershocks, Earth Planets Space, 57, 417-428, 2005.

Sato, H., The relationship between late Cenozoic tectonic events and stress fields and basin development in northeast Japan, J. Geophys. Res., 99, 22261-22274, 1994.

Sato, H. and N. Kato, Relationship between geologic structure and the source fault of the 2004 Mid-Niigata Prefecture Earthquake, central Japan, Earth Planets Space, 57, 453-457, 2005.

Shibutani, T., Y. Iio, S. Matsumoto, H. Katao, T. Matsushima, S. Ohmi, F. Takeuchi, K. Uehira, K. Nishigami, B. Enescu, I. Hirose, Y. Kano, Y. Kohno, M. Korenaga, Y. Mamada, M. Miyazawa, K. Tatsumi, T. Ueno, H. Wada, and Y. Yukutake, Aftershock distribution of the 2004 Mid Niigata Prefecture Earthquake derived from a combined analysis of temporary online observations and permanent observations, Earth Planets Space, 57, 545-549, 2005.

Shimazaki, K., Small and large earthquakes: the effects of the thickness of seismogenic layer and the free surface, in Earthquake Source Mechanics, AGU Monograph, 37 (Maurice Ewing Ser. 6), edited by S. Das, J. Boaghtwright, and C. H. Sholz, pp. 209-216, 1986.

Shirai, T., Crustal movement during the Late Quaternary along the lower course of the Uono River, Niigata Pref., Japan. Bull. Geography, Tokyo Edu. Univ., 11, 23-35, 1967 (in Japanese).

Suzuki, Y., M. Watanabe, and D. Hirouchi, Surface earthquake fault of the Mid Niigata Prefecture earthquake in 2004, Journal of Geography (Chigaku Zassi), 113, 861-870, 2004 (in Japanese with English abstract).

Watanabe, M., Y. Suzuki, H. Tsutsumi, H. Y. Kim, and H. Sato, 1:25,000 Active Fault Map in Urban Area [Oziya district], Geographical Survey Institute of Japan, 2001 (in Japanese).

Yagi, Y., Source process of the 2004 Mid Niigata Prefecture earthquake obtained by joint inversion of near-field and teleseismic, 2005 Joint Meeting for Earth and Planetary Science, abstract, S101P-001, 2005 (in Japanese with English abstract).

Yamanaka, Y., EIC seismological note, no. 154, http://www.eri.u-tokyo.ac. jp/sanchu/Seismo_Note/, 2004.

Yanagisawa, Y., I. Kobayashi, K. Takeuchi, M. Tateishi, K. Tihara, and S. Kato, Geology of the Oziya District, With geological sheet map at 1:50,000, Geological Survey Institute of Japan, 177 pp., 1986 (in Japanese with English abstract).

Yeats. R. S., Fault related to folding with examples from New Zealand, Royal. Soc., New Zealand Bull., 24, 273-292, 1986.

H. Y. Kim (e-mail: Kim0210@eri.u-tokyo.ac.jp) and A. Okada 